\title{
Impact of superdisintegrants on efavirenz release from tablet formulations
}

YELCHURI VIJAYA RAJESH ${ }^{3, *}$ JAGDISH BALASUBRAMANIAM ${ }^{3}$ KODURI BINDU ${ }^{1}$

RAMACHANDRAN SRIDEVI ${ }^{1}$

MAROJU SWETHA ${ }^{1}$

VINAY UMESH RAO

1 International Specialty Products India Pvt Limited, 6-3-1090/A Bhupal Towers, Rajbhavan Road Somajiguda, Hyderabad-500082 India

${ }^{2}$ Daewoong Pharmaceutical Co., Ltd. Indian Branch Office, C-54/A, Techni Towers, $I V^{\text {th }}$ floor, A.P.I.E., Balanagar Hyderabad-500037, India

${ }^{3}$ RA Chem Pharma Limited, Road No 18 IDA, Nacharam, Hyderabad-500076 India

Accepted April 12, 2010

\begin{abstract}
Efavirenz (EFV) tablets of different doses were prepared by a wet granulation process using different superdisintegrants such as crosscarmellose sodium (CCS), sodium starch glycollate (SSG) and crosspovidone (CP) to evaluate the role of different disintegrants on the in vitro release of EFV. Further, the mode of addition of disintegrants on EFV dissolution from tablets containing $600 \mathrm{mg}$ of the drug was evaluated by incorporating the disintegrants extragranularly (EG), intragranularly (IG) or distributing them equally (IG and EG). In vitro dissolution of the prepared tablets was conducted using the recommended medium and a dissolution medium developed in-house, which had the ability to discriminate between the formulations.

The $t_{50}$ and $t_{80}$ values were indicative of the fact that the drug release was faster from tablet formulations containing CP. CP was able to release the drug faster than the other two disintegrants in both dissolution media and the drug release was unaffected by the mode of CP addition.
\end{abstract}

Keywords: efavirenz, superdisintegrants, granulation

EFV is a non-nucleoside reverse transcriptase inhibitor and is used as part of the highly active antiretroviral therapy for the treatment of human immunodeficiency virus type 1 (HIV) infection. It is also used in combination with other antiretroviral agents as part of an expanded post-exposure prophylaxis regimen to prevent HIV transmission for those exposed to materials associated with a high risk of HIV transmission.

EFV has poor aqueous solubility and is a BCS class II drug (1). EFV tablets of 600 $\mathrm{mg}$ are available, while lower doses (50,100 and $200 \mathrm{mg}$ ) are generally available as capsules and are prepared by a wet granulation process $(2,3)$.

*Correspondence; e-mail: rajeshyelchuri@rediffmail.com 
Superdisintegrants generally improve disintegration efficiency compared to traditional disintegrants. They are generally used at low levels in solid dosage forms, typically $1-10 \%$ of mass relative to the total mass of the dosage unit (4). Examples of superdisintegrants are crosscarmellose sodium (CCS), sodium starch glycollate (SSG) and crosspovidone $(\mathrm{CP})$, which are cross-linked cellulose, a cross-linked starch and a cross-linked polymer (polyvinyl pyrrolidone), respectively. Wet granulation is one of the frequently used techniques to prepare blends to be compressed into tablets. The disintegrant can be incorporated in the blend before granulation, referred to as intragranular addition (IG), or after granulation, referred to as extragranular addition (EG), or it can be distributed both intra and extragranularly.

\section{EXPERIMENTAL}

\section{Materials}

Efavirenz (Aurbindo Pharma Ltd., India) was purchased from the source indicated. Crosscarmellose sodium (Ac-di-sol ${ }^{\circledR}$, FMC biopolymer) and SSG (Glycol YS ${ }^{\circledR}$, Roquette) were purchased from Signet (India). Polyvinyl pyrrolidone (PVP-Plasdone K29/32), Crosspovidone (Polyplasdone XL-10) were from ISP India Pvt Ltd., India. MCC PH 101, lactose, magnesium stearate and Aerosil were purchased from Signet (India). All other reagents used were of analytical grade.

\section{Methods}

Preparation of granules. - Weighed amounts of the drug, diluent, IG superdisintegrant (if required by experimental design) and binder were passed through $0.595 \mathrm{~mm}$ sieve and pre-mixed in the granulator jar (4M-8 high shear granulator, Pro-C-Ept, Belgium) at impeller speed ranging from 1000-1200 rpm for 60 seconds. Water (8-10\% of batch size) was added at a pre-determined rate after 120 seconds, the chopper was started (2300-2500 rpm) and granulation proceeded for 10 minutes. The impeller torque and the product temperature were monitored to determine the end point of granulation. The granules were sieved through a suitable mesh and dried in an oven at $60{ }^{\circ} \mathrm{C}$ to a final moisture content of $1.5-2 \%, m / m$ (determined using a Sartorius moisture balance, Germany).

\section{Preparation of tablets}

Granules were mixed with required quantities of superdisintegrant (as required) and lubricant and blended for 5 minutes in a V-cone blender (8 rpm) to form a homogeneous powder mix and compressed using suitable punches (for $600 \mathrm{mg}$ 19/9 mm capsule shaped standard concave, for $200 \mathrm{mg} 11-\mathrm{mm}$ round concave and for $100 \mathrm{mg} 8-\mathrm{mm}$ round concave punch set) on a 16-station rotary tablet press (Cadmach model CMD4, India). Advanced Instrumentation Monitor (AIM) software (Metropolitan Computing Corporation, USA) was used with the tablet press to determine the compression force re- 
Table I. Composition of efavirenz tablets

\begin{tabular}{lrrr}
\hline Ingredient & \multicolumn{3}{c}{ Mass $(\mathrm{mg})$} \\
\hline Efavirenz & 600 & 200 & 100 \\
Microcrystalline cellulose PH 101 & 225 & 68 & 34 \\
Lactose & 225 & 80 & 40 \\
Plasdone K29/32 & 36 & 12 & 6 \\
SLS & 30 & 12 & 6 \\
Disintegrant ${ }^{\mathrm{a}, \mathrm{b}}$ & 60 & 20 & 10 \\
Magnesium stearate & 12 & 4 & 2 \\
Aerosil & 12 & 4 & 2 \\
Total tablet mass & 1200 & 400 & 200 \\
\hline
\end{tabular}

a Disintegrants: CCS - crosscarmellose solidum, SSG - solidum starch glycollate, CP - crosspovidone.

b Disintegrants were incorporated intra (IG), extra (EG) or $50 \%$ of disintegrant intra and $50 \%$ disintegrant extragranularly.

quired to give tablets of approximately equal hardness for the various doses used in the study. The formulae of the tablets prepared are shown in Table I.

\section{Hardness and friability determination}

The hardness of the prepared tablets was determined 24 hours after compression using an Erweka hardness tester (Erweka TBH 310 MD, Germany), which also measures the tablet diameter. Ten tablets were tested for hardness from each batch and the mean and SD were calculated.

Pre-weighed 20 tablets were placed in a plastic chambered friabilator (Erweka TAR 200, Germany) attached to a motor revolving at a speed of $25 \mathrm{rpm}$ for $4 \mathrm{~min}$. The tablets were then de-dusted, reweighed and percentage mass loss (friability) was calculated.

\section{Disintegration time}

Disintegration time of the prepared tablets was measured in $900 \mathrm{~mL}$ of purified water at $37^{\circ} \mathrm{C}$, using an Erweka TAR series tester. Disintegration time of 12 individual tablets was recorded.

\section{Content uniformity}

The prepared tablet formulations were assayed for drug content. Ten tablets were randomly selected from each batch and pulverized to a fine powder. Weighed aliquots containing an amount of powder equivalent to a single dose were taken in triplicate and assayed for the drug content using HPLC (Waters Corp., MA, USA). Buffer $\left(0.01 \mathrm{~mol} \mathrm{~L}^{-1}\right.$ of ammonium acetate solution, $\mathrm{pH}$ adjusted to 7.5 using dilute ammonia) mixed with acetonitrile (1:1) was used as the mobile phase at a flow rate of $1.5 \mathrm{~mL} \mathrm{~min}^{-1} . \mathrm{C}_{18}$ column of $250 \times 4.6 \mathrm{~mm}, 5 \mu \mathrm{m}$ (BDS Hypersil) maintained at $25^{\circ} \mathrm{C}$ was used for separation of the 
drug. The injected volume was $20 \mu \mathrm{L}$ and the eluate was detected for EFV using a UV detector (Model 8453 Agilent Technologies, Germany) at $252 \mathrm{~nm}$. The total run time was 20 minutes.

\section{Differential scanning calorimetry (DSC)}

DSC was used to characterize the thermal properties of the drug in the compressed tablet using appropriate controls. The DSC thermograms were recorded using a differential scanning calorimeter (Q 1000, TA Instruments, USA). Ultra-high pure nitrogen

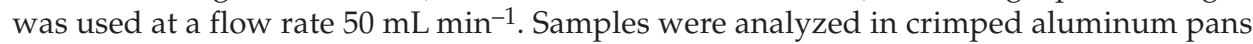
and heated from $20-200{ }^{\circ} \mathrm{C}$ at a linear heating rate of $20{ }^{\circ} \mathrm{C} \mathrm{min}-1$.

\section{In vitro dissolution studies}

Dissolution studies of the prepared tablets were carried out using a USP apparatus II (Vankel VK, USA). Dissolution was performed in $1000 \mathrm{~mL}$ of water with $2 \%$ sodium lauryl sulfate (SLS) (FDA recommended medium, 5) and with $1000 \mathrm{~mL}$ water with $0.2 \%$ SLS (discriminatory medium), at $37 \pm 0.5^{\circ} \mathrm{C}$ and at $50 \mathrm{rpm}$. An auto sampler, coupled to the dissolution apparatus was programmed to withdraw and replace $10 \mathrm{~mL}$ of the dissolution medium at 5, 10, 15, 30, 45 and 60 minutes. The withdrawn samples were analyzed for EFV content spectrophotometrically at $252 \mathrm{~nm}$, after appropriate dilution with the respective medium if required. The time required for 50 and $80 \%$ of drug to be released $\left(t_{50}\right.$ and $\left.t_{80}\right)$ was used to compare the dissolution results. The $t_{50}$ and $t_{80}$ were determined by fitting the dissolution data to a four parametric logistic model using the Marquardt-Levenberg algorithm (Sigmaplot 9.0 SPSS Inc., Chicago, USA) (6):

$$
y=\min +\frac{\max -\min }{1+10^{\left[\log E C_{50}-x\right] \times s l o p e}}
$$

In this equation, $y$ represents the cumulative $\%$ of drug released, $x$ is the time in minutes, min is the baseline of $\%$ drug released at time 0 , max is the plateau of $\%$ drug released at 60 minutes, and the slope is the slope of the curve at transition center $\left(E C_{50}\right)$.

\section{RESULTS AND DISCUSSION}

Only a few reports on the three modes of addition of disintegrants are available. For example, Gordon (7) demonstrated that EG addition was far superior to other modes of incorporation in releasing the principal tablet component. Preetha et al. (8) showed that the solubility of the main component may not be influential in determining the mode of disintegrant incorporation, but the solubility and nature of the drug may be important in selecting the disintegrant of choice.

Mass and thickness of the prepared tablets were within $1202.4 \pm 21.2 \mathrm{mg}$ and $3.54 \pm$ $0.5 \mathrm{~mm}$, respectively. Further, the hardness of the prepared tablets was maintained at 
$120 \pm 5 \mathrm{~N}$ and the friability was much lower than $1 \%$. All formulations demonstrated good content uniformity, varying from $98.6 \pm 0.1$ to $102.2 \pm 0.2 \%$ (Table II).

All tablets disintegrated rapidly in the USP disintegration test. The disintegration time was dependent on the type of disintegrant used. The disintegration times of $600 \mathrm{mg}$ tablets, where the disintegrants were added EG, IG or distributed equally between the two phases, showed that tablets prepared with $\mathrm{CP}$ showed no difference in disintegration times, while the disintegration times increased for tablets containing CCS and SSG, when these were added IG or distributed equally between the two phases (Table II). The disintegration times of tablets containing CCS and SSG IG increased almost 1.5 times compared to the respective disintegration time of the tablets containing these disintegrants, added EG.

In general, tablets containing $\mathrm{CP}$ as disintegrant disintegrated more rapidly compared to tablets containing CCS and SSG. Out of the three disintegrants studied, SSG showed longer disintegration time at all three dose levels of the EFV studied. SSG and CCS generally swell rapidly and the extent of swelling of SSG is more than that of CCS, which might have resulted in marginally slower disintegration time of tablets prepared with SSG. This is in accord with earlier findings (9).

$\mathrm{CP}$ polymers are densely cross-linked homopolymers of N-vinyl-2-pyrrolidones. Their porous particle morphology enables them to rapidly absorb liquids into the tablet by capillary action and to generate rapid volume expansion and hydrostatic pressures that result in tablet disintegration.

Table II. Physicochemical characteristics of EFV tablets

\begin{tabular}{|c|c|c|c|c|c|c|}
\hline \multirow{2}{*}{$\begin{array}{c}\text { Super } \\
\text { disintegrant }\end{array}$} & \multirow{2}{*}{$\begin{array}{l}\text { Physical } \\
\text { parameter }\end{array}$} & \multicolumn{5}{|c|}{ Drug + superdisintegrant } \\
\hline & & $600 \mathrm{mg}$ EG & $600 \mathrm{mg}$ IG & $\begin{array}{c}600 \mathrm{mg} \\
\mathrm{EG}+\mathrm{IG}\end{array}$ & 200 mg EG & 100 mg EG \\
\hline \multirow{4}{*}{ CCS } & Hardness (N) & $122.5 \pm 1.2$ & $121.4 \pm 1.0$ & $123.5 \pm 2.1$ & $124.2 \pm 0.8$ & $121.4 \pm 1.0$ \\
\hline & Friability (\%) & 0.14 & 0.18 & 0.16 & 0.11 & 0.10 \\
\hline & $\begin{array}{l}\text { Disintegration } \\
\text { time (min) }\end{array}$ & 5.14 & 8.06 & 6.48 & 3.26 & 1.54 \\
\hline & Content $(\%)$ & $99.6 \pm 0.2$ & $101.5 \pm 0.2$ & $100.4 \pm 0.2$ & $98.6 \pm 0.1$ & $100.7 \pm 0.1$ \\
\hline \multirow{4}{*}{ SSG } & Hardness (N) & $120.8 \pm 1.8$ & $120.8 \pm 2.2$ & $123.8 \pm 1.6$ & $120.6 \pm 1.9$ & $121.6 \pm 2.4$ \\
\hline & Friability (\%) & 0.17 & 0.20 & 0.18 & 0.14 & 0.15 \\
\hline & $\begin{array}{l}\text { Disintegration } \\
\text { time (min) }\end{array}$ & 8.26 & 11.58 & 9.22 & 5.81 & 3.43 \\
\hline & Content $(\%)$ & $100.2 \pm 0.1$ & $101.5 \pm 0.1$ & $99.5 \pm 0.1$ & $98.7 \pm 0.2$ & $102.2 \pm 0.2$ \\
\hline \multirow{4}{*}{$\mathrm{CP}$} & Hardness (N) & $121.0 \pm 1.5$ & $123.5 \pm 1.4$ & $121.5 \pm 2.1$ & $124.4 \pm 0.6$ & $122.5 \pm 1.4$ \\
\hline & Friability (\%) & 0.11 & 0.1 & 0.13 & 0.09 & 0.07 \\
\hline & $\begin{array}{l}\text { Disintegration } \\
\text { time (min) }\end{array}$ & 3.57 & 4.06 & 4.04 & 1.42 & 0.56 \\
\hline & Content (\%) & $101.6 \pm 0.2$ & $99.3 \pm 0.2$ & $100.4 \pm 0.1$ & $98.6 \pm 0.1$ & $99.5 \pm 0.1$ \\
\hline
\end{tabular}

For acronyms see Table I. 
Visually, tablets formulated with CP could be seen to rapidly disintegrate into more or less uniform fine particles, while tablets formulated with CCS and SSG appeared to disintegrate much more slowly into more or less uniform coarser particles.

\section{In vitro dissolution studies}

In general, the recommended dissolution medium for in vitro dissolution testing can be used for formulation development and it is typically non-discriminatory between formulation ingredients. Drug release of a poorly soluble drug like EFV, as used in the study, is usually driven more by the medium than by the formulation ingredients. Discriminatory dissolution profiles are highly desirable for distinguishing between products showing differences in pharmaceutical attributes (formulation or manufacturing process differences) as is the case in the present study, wherein the difference in formulation was only with respect to the disintegrant used (10-13).

Figure 1 shows the dissolution profile of 600 -mg EFV tablet in water containing different concentrations of SLS containing CP as disintegrant. The dissolution studies in the recommended medium showed that tablets with $\mathrm{CP}$ as disintegrant released the drug faster than the other disintegrants (Table III), and hence it was used for determining a discriminatory dissolution medium. This is evidenced by the $t_{50}$ and $t_{80}$ value. To arrive at a discriminatory medium, the approach adopted was to progressively decrease the concentration of SLS used. From the dissolution profile shown in Fig. 1, it was decided to use water with $0.2 \%$ SLS as the discriminatory medium. The concentrations above $0.2 \%$ failed to show much difference in the rate and extent of drug release while concen-

Table III. $\mathrm{t}_{50}$ and $\mathrm{t}_{80}$ of efavirenz tablet formulations

\begin{tabular}{|c|c|c|c|c|c|c|c|}
\hline & \multirow[b]{2}{*}{ Superdisintegrant } & & \multicolumn{5}{|c|}{ Drug + superdisintegrant } \\
\hline & & & $600 \mathrm{mg}$ EG & $600 \mathrm{mg}$ IG & $\begin{array}{c}600 \mathrm{mg} \\
\mathrm{EG}+\mathrm{IG}\end{array}$ & $200 \mathrm{mg}$ EG & $100 \mathrm{mg}$ EG \\
\hline \multirow{4}{*}{ CCS } & \multirow{2}{*}{$t_{50}$ (minutes) } & $\mathrm{RM}$ & 17.4 & 30.07 & 25.68 & 10.8 & 8.16 \\
\hline & & $\mathrm{DM}$ & 29.53 & ND & ND & 43.68 & 38.28 \\
\hline & \multirow{2}{*}{$t_{80}$ (minutes) } & $\mathrm{RM}$ & 44.27 & NA & 49.56 & 28.37 & 18.13 \\
\hline & & $\mathrm{DM}$ & NA & ND & ND & NA & 58.26 \\
\hline \multirow{4}{*}{ SSG } & \multirow{2}{*}{$t_{50}$ (minutes) } & $\mathrm{RM}$ & 27.66 & 39.54 & 27.54 & 19.17 & 16.96 \\
\hline & & $\mathrm{DM}$ & NA & ND & ND & NA & NA \\
\hline & \multirow{2}{*}{$t_{80}$ (minutes) } & $\mathrm{RM}$ & NA & NA & NA & 52.02 & 35.37 \\
\hline & & $\mathrm{DM}$ & NA & ND & ND & NA & NA \\
\hline \multirow{4}{*}{$\mathrm{CP}$} & \multirow{2}{*}{$t_{50}$ (minutes) } & $\mathrm{RM}$ & 9.62 & 8.53 & 10.8 & 9.6 & 10.09 \\
\hline & & $\mathrm{DM}$ & 22.21 & ND & ND & 19.72 & 18.69 \\
\hline & \multirow{2}{*}{$t_{80}$ (minutes) } & $\mathrm{RM}$ & 27.54 & 29.82 & 28.23 & 25.21 & 20.85 \\
\hline & & $\mathrm{DM}$ & NA & ND & ND & 56.75 & 45.71 \\
\hline
\end{tabular}

NA - not able to achieve desired \% of drug release; ND - not done; RM - FDA recommended dissolution medium; DM - discriminatory in-house medium.

For acronyms see Table I. 
Fig. 1. Effect of different concentrations of sodium lauryl sulfate (SLS) on EFV release from 600-mg tablets containing crosspovidone as disintegrant. Values represent mean $\pm \mathrm{SD}(n=6)$.

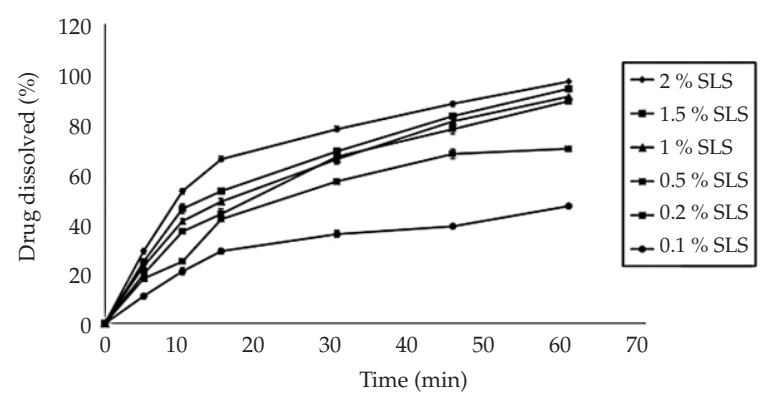

tration of SLS below $0.2 \%$, i.e., $0.1 \%$, failed to achieve any meaningful release since the amount of drug dissolved was less than $40 \%$.

The dissolution profile of 600-mg EFV tablets prepared with different superdisintegrants in the recommended medium and in the discriminatory medium is shown in Figs. 2 a and b. The results show that the tablets prepared with CP showed faster dissolution than the corresponding tablets prepared with CCS or SSG, in both media, as also evidenced by the $t_{50}$ and $t_{80}$ values (Table III). The results clearly demonstrate the superiority of $\mathrm{CP}$ to enhance the release of the drug even in the discriminatory medium. The concentration of SLS used was just below the critical micelle concentration of SLS, which is $0.25 \%, m / V(14)$ and shows that the choice of superdisintegrant has a significant impact on drug dissolution. However, a similar trend was observed for tablets, with lower doses; the difference was not very apparent between the tablets containing CCS and CP as disintegrants, especially at the 100-mg dose level. The solubility of EFV, being a poorly soluble drug, is expected to be indirectly proportional to the concentration of the drug.

In an earlier study (13) EFV capsules with rapid dissolution were formulated using SSG as superdisintegrant. However, the concentration of SSG used in this study was

a)

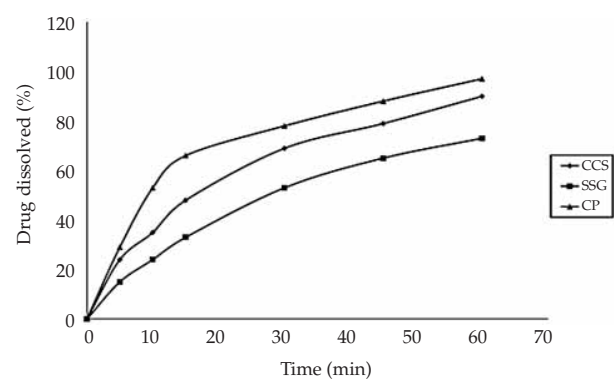

b)

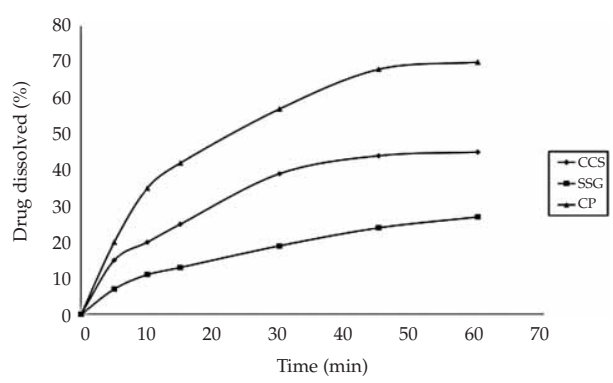

Fig. 2. Dissolution of efavirenz from 600-mg tablets prepared using different superdisintegrants in: a) $1000 \mathrm{~mL}$ of water with $2 \%$ solidum lauryl sulfate (SLS) (FDA recommended medium), and b) $1000 \mathrm{~mL}$ of water with $0.2 \%$ SLS (discriminatory in-house medium). Values represent mean \pm SD ( $n$ =6). For acronyms see Table I. 
high (20\% or more) and the study did not compare capsules prepared with similar concentrations of other disintegrants such as CCS and CP. In the present study, we demonstrated that among the three disintegrants studied, CP was able to increase the dissolution rate of EFV from the tablet formulation at $5 \%$ level, which was significantly less than in the reported study.

The dissolution profiles of 600-mg EFV tablets prepared by varying the mode of incorporation of the different disintegrants are shown in Fig. 3a-c. The overall release of EFV from tablets containing SSG added EG was much lower than that of the tablets containing CP as disintegrant, as discussed earlier. Incorporation of CCS and SSG IG seemed to retard the drug release. The results correlated well with the disintegration times of tablets, as discussed earlier.

Fig. 4 shows the thermograms recorded for pure EFV, lactose, blend of EFV and lactose at the same ratio as in the tablet and the EFV tablets containing different disintegrants. It was observed that the characteristic endotherms for both EFV and lactose showed a slight shift in the thermogram of the blend. This could be attributed to the fact that lactose may act as an impurity to EFV. Thermograms of the tablets showed a slight reduction in the endothermic transition of the drug with respect to the endothermic transition of EFV observed in the thermogram of the blend. In order to ascertain whether the observed reduction in peak intensity was caused by loss of crystallinity of the drug or its dilution (due to the presence of other tablet excipients), \% crystallinity was determined using the formula:

$$
\% \text { crystallinity }=100 \times \Delta H_{\mathrm{s}} /\left(\Delta H_{\mathrm{c}} \times \mathrm{C}\right)
$$

$\Delta H_{\mathrm{S}}$ is the enthalpy of fusion of EFV in EFV/lactose blend, $\Delta H_{\mathrm{c}}$ is the enthalpy of fusion of EFV in crushed tablet. The enthalpy of fusion of the drug in the lactose-EFV blend was used for calculation of \% crystallinity of the drug in the tablet instead of enthalpy of
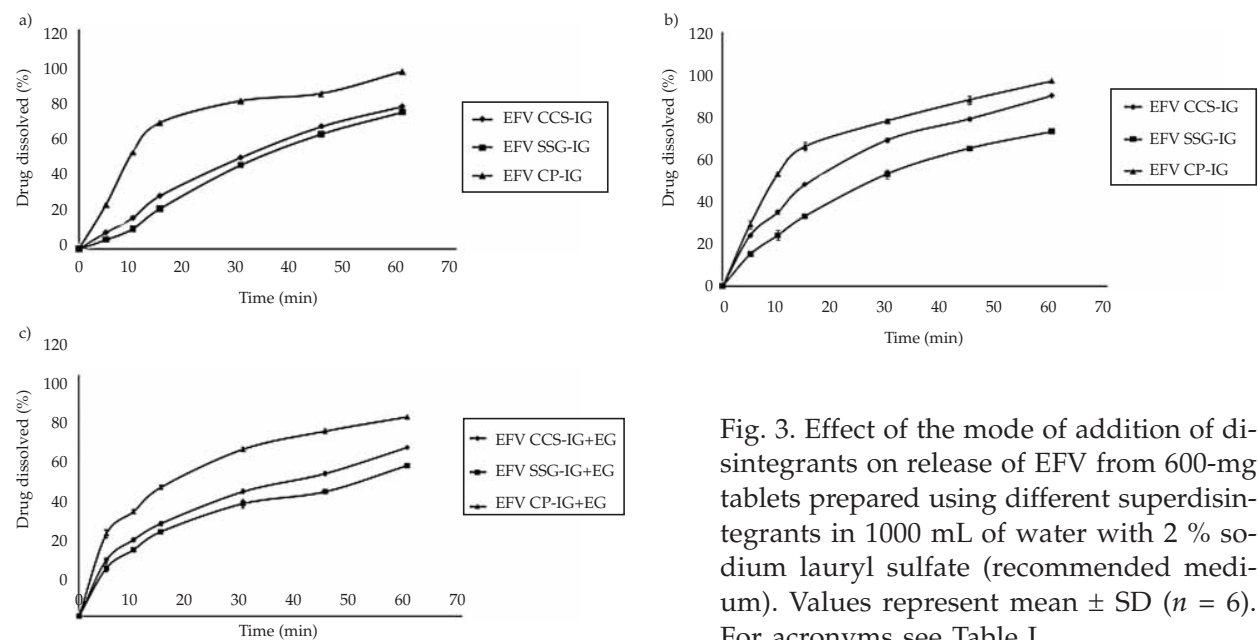

Fig. 3. Effect of the mode of addition of disintegrants on release of EFV from 600-mg tablets prepared using different superdisintegrants in $1000 \mathrm{~mL}$ of water with $2 \%$ sodium lauryl sulfate (recommended medium). Values represent mean $\pm \operatorname{SD}(n=6)$. For acronyms see Table I. 
Fig. 4. DSC of efavirenz tablets containing varying concentrations of different superdisintegrants (for some acronyms see Table I).

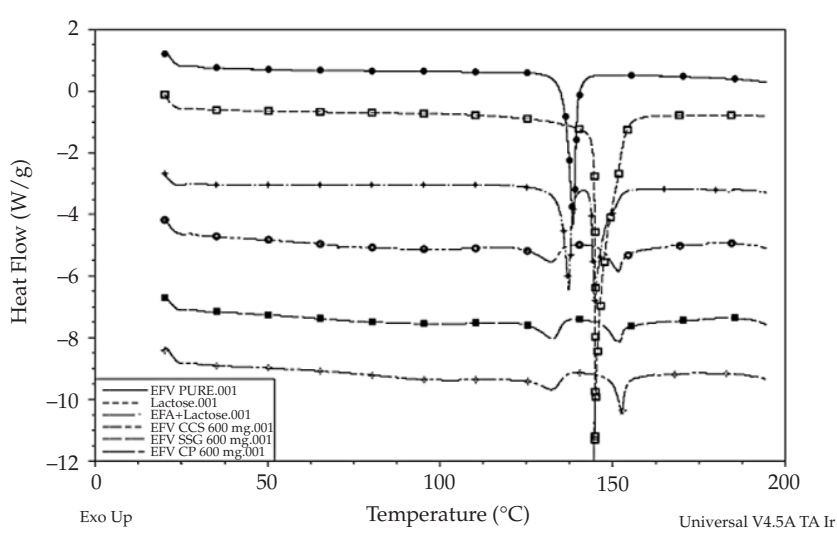

fusion of pure drug since this would take into account the effect of lactose on the solid state characteristics of EFV. The \% crystallinity of the drug in the prepared tablets was between 90 and $94 \%$, suggesting that the other tablet excipients and the process of preparing the tablets did not influence the solid state characteristics of the drug. Hence, it could be deduced that the improvement observed in the dissolution was not due to the possible amorphization of the drug but only to the excipients used in the tablet. The only excipient that was different in the tablets prepared was the disintegrant.

\section{CONCLUSIONS}

The comprehensive study conducted to evaluate the impact of different superdisintegrants on the dissolution rates of EFV from tablet formulations containing different doses of the drug showed that $\mathrm{CP}$ provided the fastest rate of dissolution both in the USFDA recommended and the discriminatory (in-house developed) media. Further, the mode of disintegrant addition did not affect the drug release when $\mathrm{CP}$ was used as disintegrant, unlike CCS or SSG, wherein IG addition decreased the drug release appreciably in both cases.

\section{REFERENCES}

1. S. Sathigari, G. Chadha, Y-H. Lee, N. Wright, D. Parsons, V. Rathnagiri, O. Fasina and R. Babu, Physicochemical characterization of efavirenz-cyclodextrin inclusion complexes, AAPS PharmSciTech. 10 (2009) 81-87; DOI: 10.1208/S12249-008-9180-3.

2. K. Kesavan, V. U. Rao, K. Bindu, P. S. Rajinikanth, J. K. Pandit and J. Balasubramaniam, Immediate release tablets of valsartan and efavirenz: Role of concentration of superdisintegrant, Ars. Pharm. 49 (2008) 229-243.

3. W. T. Makooi-Morehead, J. D. Buehlar and B. R. Landmann, Formulation of fast-dissolving efavirenz capsules or tablets using super-disintegrants, US Pat. 6,238,695 B1, 29 May 2001; http:/ / www.freepatentsonline.com/65551333.html/accessed April 12, 2010. 
4. N. Zhao and L. L. Augsburger, The influence of swelling capacity of superdisintegrants in different $\mathrm{pH}$ media on the dissolution of hydrochlorothiazide from directly compressible tablets, AAPS PharmSciTech. 6 (2005) E120-126.

5. Food and Drug Administration Department, Efavirenz, http://www.accessdata.fda.gov/ scripts/cder/dissolution/dsp_SearchResults_Dissolutions.cfm?PrintAll=1, accessed Feb 05, 2010.

6. J. Balasubramaniam, K. Bindu, V. U. Rao, D. Ray, R. Haldar and A. W. Brzeczko, Effect of superdisintegrants on dissolution of cationic drugs, Dissol. Technol. 15 (2008) 18-25.

7. M. S. Gordon, V. S. Rudraraju, K. Dani and Z. T. Chowhan, Effect of the mode of superdisintegrants incorporation on dissolution in wet granulated tablets, J. Pharm. Sci. 82 (1993) 220-226.

8. B. Preetha, J. K. Pandit, V. U. Rao, K. Bindu, Y. V. Rajesh and J. Balasubramaniam, Comparative evaluation of mode of incorporation of superdisintegrants on dissolution of model drugs from wet granulated tablets, Acta Pharm. Sci. 50 (2008) 229-236.

9. Y. S. Yen, C. R. Chen, M. T. Lee and L. C. Chen, Investigation of dissolution enhancement of nifedipine by deposition on superdisintegrants, Drug. Dev. Ind. Pharm. 23 (1997) 313-317; DOI: $10.3109 / 03639049709149809$.

10. J. Kukura, J. L. Baxter and F. J. Muzzio, Shear distribution and variability in the USP apparatus 2 under turbulent conditions, Int. J. Pharm. 279 (2004) 9-17; DOI: 10.1016/j.ijpharm.2004.03.033.

11. L. G. McCarthy, C. Kosiol, A. M. Healy, G. Bradley, J. C. Sexton and O. I. Corrigan, Simulating the hydrodynamic conditions in the United States Pharmacopeia paddle dissolution apparatus, AAPS Pharm.Sci.Tech. 4 (2005) 1-16.

12. S. A. Qureshi and J. Shabnam, Cause of high variability in drug dissolution testing and its impact on setting tolerances, Eur. J. Pharm. Sci. 12 (2001) 271-276; DOI: 10.1016/S0928-0987(00) 00174-3.

13. S. A. Qureshi, Developing discriminatory drug dissolution tests and profiles: Some thoughts for consideration on the concept and its interpretation, Dissol. Technol. 13 (2006) 18-23.

14. M. S. Kim, S. J. Jin, J. S. Kim, H. J. Park, H. S. Song, R. H. H. Neubert and S. J. Hwang, Preparation, characterization and in vivo evaluation of amorphous atorvastatin calcium nanoparticles using supercritical antisolvent (SAS) process, Eur. J. Pharm. Biopharm. 69 (2008) 454-465; DOI: 10.1016/j.ejpb.2008.01.007.

\author{
$S A \check{Z} E T A K$
}

\title{
Utjecaj superdezintegratora na oslobađanje efavirenca iz tableta
}

\author{
YELCHURI VIJAYA RAJESH, JAGDISH BALASUBRAMANIAM, KODURI BINDU, \\ RAMACHANDRAN SRIDEVI, MAROJU SWETHA I VINAY UMESH RAO
}

$\mathrm{U}$ radu je opisana priprava tableta s različitim dozama efavirenca (EFV) metodom vlažne granulacije. Za tabletiranje korišteni su različiti superdezintegratori, poput natrijeve kroskarmeloze (CCS), natrijeva škrobnog glikolata (SSG) i krospovidona (CP), kako bi se procijenio utjecaj vrste i načina dodavanja dezintegratora na oslobađanje EFV in vitro. $\mathrm{U}$ tu svrhu pripravljene su tablete sa $600 \mathrm{mg} \mathrm{EFV}$, a dezintegrator je dodavan ekstragranularno (EG), intragranularno (IG) ili je bio podjednako raspršen (IG i EG). In vitro oslobađanje praćeno je $u$ preporučenom mediju i mediju izrađenom u našem laboratoriju kako bi se uočila razlika između formulacija. Vrijednosti $t_{50}$ i $t_{80}$ ukazuju na to da je oslobađanje lijeka brže iz formulacija koje sadrže CP u oba medija. Način dodava- 
nja CP nema utjecaj na oslobađanje lijeka, osim za CCS, gdje se ekstragranularno dodavanje pokazalo povoljnijim.

Ključne riječi: efavirenc, superdezintegratori, granulacija

International Specialty Products India Pvt Limited, 6-3-1090/A, Bhupal Towers, Rajbhavan Road, Somajiguda, Hyderabad-500082, India

Daewoong Pharmaceutical Co., Ltd., Indian Branch Office, C-54/A, Techni Towers, IV th floor, A.P.I.E., Balanagar, Hyderabad-500037, India

RA Chem Pharma Limited, Road No 18, IDA, Nacharam, Hyderabad-500076, India 